\title{
Pariwisata Berbasis Masyarakat di Desa Sekapuk: Sebuah Participatory Action Research
}

\author{
Agung Yoga Asmoro ${ }^{*}$, Firdaus Yusrizal ${ }^{2}$, Indra Saputra ${ }^{3}$ \\ ${ }^{1}$ Akademi Pariwisata Nasional, Jl. Mayjend Sutoyo S No.126, Banjarmasin \\ ${ }^{2}$ Universitas Riau, Simpang Baru, Pekanbaru, Riau \\ 3 Sekolah Tinggi Ilmu Ekonomi Nasional, Jl. Mayjend Sutoyo S, Banjarmasin \\ * Corresponding Author Email: agungyoga@gmail.com, Telp: +6282139695715
}

\section{Received: 28 August 2020; Revised: 04 February 2021; Accepted: 29 Maret 2021}

\begin{abstract}
Abstrak: Penelitian ini bertujuan untuk memahami kondisi aktual kepariwisataan berbasis masyarakat (CBT) di Desa Sekapuk dengan menganalisis pelaksanaan prinsip-prinsip CBT. CBT patut diimplementasikan karena masyarakat adalah pihak yang seyogianya menjadi pelaku utama berbagai kegiatan kepariwisataan, sehingga manfaat dari pariwisata dapat dirasakan langsung oleh masyarakat. Penelitian ini merupakan Community-Based Research (CBR) yang dilakukan dengan pendekatan Participatory Action Research (PAR). Implementasi CBT di Desa Sekapuk secara garis besar sejalan dengan prinsip-prinsip CBT pada aspek: partisipasi dan pemberdayaan masyarakat; kemitraan dengan pemangku kepentingan terkait; pengakuan dari otoritas terkait; peningkatan kesejahteraan sosial; keadilan dan transparansi dalam pembagian manfaat; peningkatan hubungan dengan ekonomi lokal dan regional; dan kemandirian finansial. Penelitian menemukan masih perlu ditingkatkan kinerja dalam aspek penghargaan terhadap budaya dan tradisi lokal, kontribusi terhadap konservasi sumber daya alam; dan upaya peningkatan pengalaman pengunjung.
\end{abstract}

Kata Kunci: community-based tourism, partisipasi masyarakat, pemberdayaan masyarakat, kemitraan, sekapuk

\section{Community-Based Tourism in Sekapuk Village: a Participatory Action Research}

\begin{abstract}
This study aims to understand the actual conditions of community-based tourism (CBT) in Sekapuk Village by analyzing the implementation of CBT principles. CBT should be implemented because the local community is supposedly the main actors for various tourism activities to maximize the direct benefits of tourism. This research is Community-Based Research (CBR) conducted using the Participatory Action Research (PAR) approach. The implementation of CBT in Sekapuk Village is broadly in line with the principles of CBT in the aspects of community participation and empowerment; partnerships with relevant stakeholders; recognition from relevant authorities; increase in social welfare; fairness and transparency in benefit-sharing; improved relations with local and regional economies; and financial independence. The research found that performance needs to be improved in terms of respect for local culture and traditions, contribution to the conservation of natural resources; and visitor experience enhancement efforts.
\end{abstract}

Keywords: community-based tourism, community participation, community empowerment, partnerships, Sekapuk

How to Cite: Asmoro, A Y, Yusrizal, F, Saputra, I (2021). Pariwisata Berbasis Masyarakat di Desa Sekapuk: Sebuah Participatory Action Research. JPPM (Jurnal Pendidikan dan Pemberdayaan Masyarakat), 8(1), 30-47.

Doi: https://doi.org/10.21831/jppm.v8i1.34144 


\section{JPPM (Jurnal Pendidikan dan Pemberdayaan Masyarakat), 8 (1), 2021 - 31}

Agung Yoga Asmoro, Firdaus Yusrizal, Indra Saputra

\section{PENDAHULUAN}

Beberapa tahun ke belakang tren pariwisata telah semakin bergeser (John \& Elizabeth, 2017). Wisatawan milenial juga telah mendorong pergeseran nilai dari keserakahan kapitalisme akhir abad ke-20, yang pada akhirnya meninggalkan mass tourism, menuju perhatian pada kesejahteraan dan kemajuan sosial seperti pada alternative tourism (Kaihatu dkk., 2020; Sheldon \& Fesenmaier, 2017). Dari berbagai model pariwisata alternatif yang tersedia, Community-Based Tourism (CBT) atau pariwisata berbasis masyarakat merupakan salah satu di antaranya (Giampiccoli \& Saayman, 2014; Mtapuri \& Giampiccoli, 2019). Sebenarnya, terminologi CBT muncul pada pertengahan tahun 1990-an (Albert J. dkk., 2018) diawali Peter E. Murphy yang pada tahun 1985 memaparkan konsep community tourism (Murphy, 1985). CBT umumnya berskala kecil dan melibatkan interaksi antara pengunjung dan komunitas tuan rumah, yang selama ini umumnya dikembangkan di daerah pedesaan dan regional (Yanes dkk., 2019; Zielinski dkk., 2020).

CBT dipahami sebagai bentuk kepariwisataan yang dimiliki dan dikelola oleh masyarakat, serta untuk kemanfaatan masyarakat setempat (Hall, 2005) dan (Bjork, 200o) dalam (Laire \& Gutierrez, 2019, hlm. 24). Ini berarti bahwa CBT adalah bentuk pariwisata lokal yang mengutamakan penyedia dan pemasok layanan lokal dan berfokus pada menafsirkan dan mengomunikasikan budaya dan lingkungan lokal kepada wisatawan (Asli D.A. Tasci \& Yilmaz, 2013). Di banyak negara, pariwisata berkelanjutan, pariwisata berbasis komunitas, wisata pedesaan dan ekowisata memiliki tujuan yang serupa, yaitu merencanakan pariwisata untuk menjaga warisan budaya suatu destinasi dan meningkatkan warisan alamnya sekaligus meningkatkan kesejahteraan sosial ekonomi masyarakat (Havadi Nagy \& Espinosa Segui, 2020; Sutresna dkk., 2019:74-75).

Di Indonesia sendiri pada hakikatnya CBT bukanlah suatu hal yang asing. Walau secara terminologi mungkin baru dikenal dalam beberapa dekade belakangan ini, namun pada realitanya CBT sudah melekat pada histori kepariwisataan Indonesia pada beberapa destinasi wisata populer, sebut saja Ubud dan Yogyakarta yang kepariwisataannya amat berkaitan dengan model CBT. Puri Agung Ubud tercatat semenjak awal 1900-an sudah menjadi destinasi wisata (Anom dkk., 2017:60; MacRae, 2015:69) dan jujukan banyak pelukis mancanegara semacam pelukis asal Eropa Walter Spies (Jerman) dan Rudolf Bonnet (Belanda) (Vickers, 2019:255). Sementara Kraton Yogyakarta dan Surakarta adalah penguasa Jawa kala wisatawan asal Eropa mula-mula berwisata ke Yogyakarta pada abad ke-19 (Cohen, 2010:49). Konteks sebagai pemuka masyarakat, raja-raja ini sudah memerankan CBT jauh sebelum konsep CBT digaungkan.

Semenjak 1970-an industri pariwisata menjelma menjadi mesin ekonomi raksasa. Enclave tourism dan resort-resort pun bermunculan di destinasi wisata utama. Pemodal besar yang umumnya merupakan investor dari luar daerah mengeruk keuntungan dari pariwisata, sementara masyarakat lokal seringkali hanya menjadi objek penderita dan penonton dari perubahan pesat pariwisata (Davis \& Morais, 2004; Freitag, 1994; Mbaiwa, 2005). Freitag (1994) dalam penelitiannya menemukan bahwa kelemahan yang melekat pada enclave tourism sebagai bentuk pengembangan pedesaan adalah bahwa pengelolaan resor enklaf berusaha meminimalkan pertukaran ekonomi antara wisatawan dan bisnis lokal dalam rangka meningkatkan margin keuntungan resor. Sementara Mbaiwa (2005) secara ekstensif mengungkapkan bahwa, perusahaan wisata safari dan investor mancanegara mendominasi industri pariwisata di Delta Okavango. Dominasi asing terhadap kepemilikan fasilitas pariwisata telah menyebabkan repatriasi pendapatan pariwisata, dominasi posisi manajemen atas oleh ekspatriat, gaji yang rendah untuk warga setempat, dan kegagalan pariwisata secara umum untuk berkontribusi secara signifikan terhadap pengentasan kemiskinan pedesaan di wilayah Okavango. Kesenjangan yang tinggi ini menimbulkan berbagai persoalan sosial, ekonomi dan budaya yang mengganggu kepariwisataan (Aili dkk., 2007; Shaw \& Shaw, 1999), sekaligus juga menyimpang dari cita-cita luhur pariwisata sebagai alat dan sarana untuk meningkatkan taraf 


\section{JPPM (Jurnal Pendidikan dan Pemberdayaan Masyarakat), 8 (1), 2021 - 32}

Agung Yoga Asmoro, Firdaus Yusrizal, Indra Saputra

hidup dan martabat masyarakat (Picard, 2006:192-204). Kehadiran CBT seolah menjadi angin segar dan merupakan jawaban akan adanya fenomena ini.

CBT saat ini sedang dikembangkan di berbagai belahan dunia (Asia, Afrika dan Amerika Latin) sebagai alternatif dari pariwisata tradisional dan sebagai alat untuk pembangunan berkelanjutan di destinasi yang belum berkembang (Maldonado-Erazo dkk., 2020). CBT menempatkan masyarakat setempat sebagai aktor utama di dalam kepariwisataan, semenjak tahap perencanaan hingga pelaksanaan (Hermawan, 2017:114; Resnawaty, 2016:107). Harapannya tentu bahwa kegiatan CBT akan membawa manfaat kepada masyarakat berupa: 1) pengembangan dan peningkatan kapasitas sumberdaya manusia; 2) mempromosikan kebudayaan lokal;3) memperkuat peran wanita dalam lingkungan; 4) pengentasan kemiskinan, penciptaan lapangan dan membuka kesempatan kerja; dan 5) pertukaran budaya (TwiningWard, 2007). Landasan yuridis pemberdayaan masyarakat di dalam kepariwisataan Indonesia ini tertuang dalam UU RI Nomor 10 Tahun 2009 pasal 5e, sedangkan PERMENBUDPAR No: PM.26/UM.oo1/MKP/2010 secara spesifik merupakan pedoman umum tentang Program Nasional Pemberdayaan Masyarakat (PNPM) Mandiri Pariwisata Melalui Desa Wisata.

Dengan ditopang landasan yuridis tersebut, maka pertumbuhan Desa Wisata di Indonesia beberapa tahun belakangan ini meningkat pesat. Pada Provinsi Jawa Timur, tercatat ada 479 Desa Wisata (CNN Indonesia, 2020) di mana terdapat 26 (dua puluh enam) di antaranya merupakan desa wisata unggulan dengan tingkat kunjungan wisatawan yang signifikan (Kompas.com, 2019). Dari sekian ratus desa wisata tersebut, Desa Sekapuk (Desa Sekapuk, 2020) di Kecamatan Ujungpangkah, Kabupaten Gresik adalah salah satu di antaranya.

CBT umumnya melayani segmen pasar wisata minat khusus seperti wisata adventure, budaya, ekowisata, atau agrowisata (Dewi dkk., 2018; Đurkin dkk., 2017; Masud dkk., 2017; Srithong dkk., 2019), dengan memanfaatkan produk dan layanan lokal untuk mendapatkan manfaat ekonomi dari keterlibatan dalam pariwisata. Dewi dkk., (2018) dalam penelitiannya menemukan bahwa keterlibatan masyarakat setempat di Desa Pemuteran, Munduk, dan Sambangan berkaitan dengan aktivitas wisata bawah laut (selam dan snorkeling), agrowisata, ekowisata dan wisata olahraga petualangan. Sementara Đurkin, dkk., (2017) menunjukkan bahwa aset wisata budaya biasanya merupakan bagian yang tidak terpisahkan dari identitas lokal, maka CBT adalah model pariwisata yang dikembangkan, dimiliki dan dikuasai oleh masyarakat setempat. Namun, tidak demikian dengan Desa Sekapuk. Dengan inovasi yang otentik, Desa Sekapuk justru mengonversi lahan bekas penambangan kapur yang telah beralih fungsi menjadi tempat pembuangan akhir, menjadi satu atraksi wisata yang kepemilikannya dimiliki oleh masyarakat setempat melalui struktur permodalan mandiri berupa saham, dikelola oleh Badan Usaha Milik Desa Sekapuk dengan menyerap puluhan tenaga kerja dan memberikan kesempatan berusaha terhadap ratusan masyarakat setempat, yang dengan atraksi wisata Bukit Kapur Setigi ini sanggup meningkatkan status Desa Sekapuk dari yang semula masuk ke dalam kategori desa tertinggal, hingga kini berstatuskan desa mandiri. Penelitian ini bertujuan untuk memahami kondisi aktual CBT di Desa Sekapuk dengan menganalisis implementasi prinsipprinsip CBT di Desa Sekapuk. Diharapkan temuan penelitian ini dapat bermanfaat sebagai masukan bagi CBT di Desa Sekapuk maupun pengembangan CBT lainnya.

\section{METODE}

Penelitian ini merupakan Community-Based Research (CBR) yang diimplementasikan dengan pendekatan Participatory Action Research (PAR). Ini merupakan salah satu pilihan dalam metodologi penelitian kualitatif deskriptif dengan integrasi metode dan observasi, dokumentasi, analisis, dan penafsiran karakteristik, pola, atribut, dan makna fenomena manusia yang diteliti (Gillis \& Jackson, 2002; Leininger, 1985) di mana tujuan dari metodologi kualitatif adalah untuk mendeskripsikan dan memahami, bukan untuk memprediksi dan mengontrol (Streubert dkk., 1995). PAR dianggap sebagai bagian dari penelitian tindakan, yang merupakan 


\section{JPPM (Jurnal Pendidikan dan Pemberdayaan Masyarakat), 8 (1), 2021 - 33}

Agung Yoga Asmoro, Firdaus Yusrizal, Indra Saputra

"pengumpulan dan analisis data secara sistematis untuk tujuan mengambil tindakan dan membuat perubahan" dengan menghasilkan pengetahuan praktis (Gillis \& Jackson, 2002:264).

Penelitian PAR terdiri dari rangkaian aksi dan refleksi secara berkelanjutan antara peneliti dan para pemangku kepentingan (Kindon dkk., 2007:15). Dalam penelitian kali ini tahapan proses penelitian dapat dilihat pada ilustrasi tabel berikut.

Tabel 1. Tahapan Penelitian CBT di Desa Sekapuk

\begin{tabular}{|c|c|}
\hline Tahapan & Kegiatan \\
\hline Tindakan & $\begin{array}{l}\text { Penulis memulai menjalin hubungan dengan pemangku kepentingan di Desa Sekapuk, yang diwakili } \\
\text { oleh unsur Kepala Desa, Bumdes, Pokdarwis, dan Badan Permusyawarahan Desa. Komunikasi ini } \\
\text { dijalin secara non formal Focus Group Discussion. Secara kolaboratif kami menemukan permasalahan } \\
\text { utama yaitu untuk mengidentifikasikan apakah pelaksanaan wisata Setigi di Desa Sekapuk sudah } \\
\text { sejalan dengan prinsip-prinsip pariwisata berbasis masyarakat (CBT), sekaligus juga menyepakati } \\
\text { bahwa pelaksanaan proses penelitian ini akan berlangsung selama kurang lebih } 1 \text { (satu) bulan, } \\
\text { tepatnya antara } 15 \text { Juli } 2020 \text { - 20 Agustus 2020 }\end{array}$ \\
\hline Refleksi & Desain penelitian, etika, proses konstruksi pengetahuan, representasi dan akuntabilitas \\
\hline Tind & $\begin{array}{l}\text { Menyepakati pentingnya keterbukaan informasi kedua belah pihak, oleh karenanya kami menyadari } \\
\text { untuk mendapatkan informasi yang lebih obyektif, maka pertanyaan yang ditujukan kepada } \\
\text { masyarakat awam dilakukan oleh tim penulis, para pemangku kepentingan yang terkait melakukan } \\
\text { pencarian informasi sehubungan dengan aspek kebijakan, dan teknis terkait dengan pengelolaan } \\
\text { usaha. Adapun upaya informasi dari wisatawan dilakukan oleh semua pihak. Kesepakatan akan } \\
\text { pembagian peran dan tanggungjawab ini tetap dilakukan secara non formal untuk menjaga dinamika } \\
\text { kelompok yang telah terjadi secara positif. Setiap temuan senantiasa didiskusikan pada berbagai } \\
\text { kesempatan baik secara verbal langsung ataupun melalui komunikasi tertulis dengan gawai. }\end{array}$ \\
\hline Refleksi & $\begin{array}{l}\text { Bersama-sama kami menyepakati beberapa poin tentang pertanyaan penelitian, yaitu: partisipasi dan } \\
\text { pemberdayaan masyarakat, kemitraan dengan pemangku kepentingan terkait, pengakuan dari } \\
\text { otoritas terkait, peningkatan kesejahteraan sosial dan pemeliharaan martabat manusia, mekanisme } \\
\text { yang adil dan transparan dalam pembagian manfaat, peningkatan hubungan dengan ekonomi lokal } \\
\text { dan regional, penghormatan budaya dan tradisi lokal, kontribusi terhadap konservasi sumber daya } \\
\text { alam, peningkatan kualitas pengalaman pengunjung, dan aspek kemandirian finansial. }\end{array}$ \\
\hline Tindakan & $\begin{array}{l}\text { Bekerja sama melaksanakan proses penelitian sembari pengkompilasian data; secara kolaboratif } \\
\text { menganalisis informasi yang didapat dari hasil penggalian informasi. }\end{array}$ \\
\hline Refleksi & $\begin{array}{l}\text { Proses penelitian berlangsung, sembari bersama-sama melakukan evaluasi yang dilakukan melalui } \\
\text { metode skala penilaian terhadap kriteria dan indikator yang telah disepakati sebelumnya }\end{array}$ \\
\hline Tindakan & $\begin{array}{l}\text { Merencanakan pelaporan hasil akhir penelitian akan disusun secara deskriptif oleh tim penulis, } \\
\text { adapun informasi atas kesimpulan penelitian digunakan sebagai umpan balik kepada semua } \\
\text { pemangku kepentingan terkait }\end{array}$ \\
\hline Refleksi & Evaluasi tindakan dan proses secara keseluruhan \\
\hline Tindakan & $\begin{array}{l}\text { Menyepakati temuan-temuan dalam penelitian sebagai landasan tindakan bagi Bumdes Sekapuk } \\
\text { untuk mengelola Wisata Setigi secara mandiri tanpa keterlibatan tim penulis. }\end{array}$ \\
\hline
\end{tabular}

Pelaksanaan penelitian ini berlangsung pada rentang waktu 15 Juli 2020 sampai dengan 20 Agustus 2020, dan bertempat di Atraksi Wisata Bukit Kapur Setigi (Selo Tirto Giri), Desa Sekapuk, Kecamatan Ujungpangkah, Kabupaten Gresik, Provinsi Jawa Timur. Subjek penelitian ini adalah partisipasi masyarakat Desa Sekapuk dalam perencanaan pariwisata dan juga pengelolaan atraksi wisata Bukit Kapur Setigi sebagai wujud konkret dari CBT di Desa Sekapuk. Hal ini diwakili oleh Bapak Abdul Halim selaku Kepala Desa Sekapuk sekaligus penggagas dan local champion dari Atraksi Wisata Bukit Kapur Setigi, Bapak Purwadi, selaku pengurus Bumdes Sekapuk merangkap Pokdarwis yang bertanggungjawab di dalam keseharian pemasaran Wisata Setigi, dan Bapak Epen, selaku perwakilan dari Badan Permusyawarahan Desa, serta beberapa narasumber perwakilan masyarakat yang tidak berkenan dicantumkan namanya.

Sumber informasi penelitian di dapat dari hasil diskusi semi kasual yang terjalin antara penulis dan perwakilan masyarakat. Dalam penelitian PAR, perwakilan masyarakat warga Desa Sekapuk turut berpartisipasi dalam desain penelitian, pengumpulan data, dan analisisinterpretasi data. Penelitian sosial kualitatif, peneliti merupakan instrumen penelitian utama dalam pengumpulan, analisis data, dan menafsirkan data (Costa, 2020:34; Merriam \& Grenier, 


\section{JPPM (Jurnal Pendidikan dan Pemberdayaan Masyarakat), 8 (1), 2021 - 34}

Agung Yoga Asmoro, Firdaus Yusrizal, Indra Saputra

2019). Untuk mengumpulkan data peneliti menggunakan beberapa instrumen bantuan berupa daftar pertanyaan, daftar tema/topik pembahasan diskusi, serta daftar periksa observasi yang digunakan untuk membantu peneliti di dalam mendapatkan data-data relevan di lapangan. Instrumen tersebut selanjutnya digunakan untuk mengumpulkan data, yang dilakukan dengan beberapa metode, diantaranya: non-formal focus group discussion, observasi lapangan, wawancara semi terstruktur, dan studi dokumentasi terhadap arsip atau dokumen terkait CBT di Desa Sekapuk. Sebagaimana telah diulas pada tabel 1, pengumpulan data dilakukan oleh 3 (tiga) kelompok utama, yaitu kami sebagai penulis yang bertanggung jawab terhadap perolehan data dari observasi, wawancara dengan pihak masyarakat awam (nonpengurus), dan wisatawan. Sementara pihak pengelola dan unsur pemangku kepentingan terkait berperan terhadap penyediaan data dan informasi sehubungan dengan aspek kebijakan, dan teknis terkait dengan pengelolaan usaha.

Analisis data adalah suatu proses pencarian dan penyusunan data secara sistematis dengan cara pengorganisasian data ke dalam kategori, menjabarkan ke dalam unit-unit, sintesa, dan selanjutnya disusun ke dalam pola (UIN Sunan Ampel Surabaya, 2015). Untuk menganalisis dan menafsirkan data kualitatif, Miles dan Huberman (1994) dalam (Valsa, 2005:113) mendefinisikan analisis data terdiri dari tiga hal, yaitu: reduksi data, menampilkan data, dan penarikan kesimpulan/verifikasi. Reduksi data mengacu pada proses pemilihan, pemfokusan, penyederhanaan, pengabstrakan dan transformasi data yang muncul dalam catatan lapangan atau transkripsi yang ditulis. Peneliti secara terus-menerus terlibat dalam reduksi data selama penyelidikan sampai kesimpulan disajikan. Proses reduksi data ini dilakukan bersama-sama antara tim penulis dan para pemangku kepentingan dalam suatu diskusi kelompok non-formal, dimana proses ini berjalan secara kasual dan alamiah. Fungsi dari tim penulis adalah lebih berperan sebagai koordinator, yang membantu pihak-pihak tersebut dalam memilih, dan menyederhanakan data ingin disajikan. Reduksi data ini mempertajam, menyortir, memfokuskan, membuang, dan mengatur data sedemikian rupa sehingga kesimpulan akhir dapat ditarik dan diverifikasi. Data yang muncul setelah proses ini adalah apa yang digunakan dalam analisis akhir (Valsa, 2005:113). Menampilkan data mencakup berbagai jenis grafik, bagan, dan jaringan. Tujuannya adalah untuk membuat informasi yang terorganisir menjadi bentuk yang segera tersedia, dapat diakses, dan ringkas sehingga analis dapat melihat apa yang terjadi dan menarik kesimpulan. Tahap akhir dari analisis data adalah kesimpulan dan verifikasi. Sejak awal, peneliti mencatat keteraturan, pola dan penjelasan. Peneliti memegang kesimpulan dengan ringan, mempertahankan skeptisisme sampai lebih eksplisit dan beralasan. Kesimpulan akhir muncul setelah proses analisis selesai (Valsa, 2005:114).

Validitas berarti kejujuran. Dalam studi kualitatif, mencapai keotentikan lebih utama daripada mewujudkan satu versi "Kebenaran". Keaslian berarti memberikan informasi sosial yang adil, jujur, dan berimbang dari berbagai sudut pandang (Neuman, 2014:218). Sehubungan dengan model penelitian ini adalah merupakan Community-Based Research, dimana menempatkan perwakilan masyarakat sebagai pelaku bagi penelitian tersebut, maka hal ini menghasilkan sebuah input data yang valid, yang ketika dianalisis secara partisipatoris, hasilnya benar-benar menggambarkan apa yang sesungguhnya terjadi (UIN Sunan Ampel Surabaya, 2015:78).

Data penelitian diverifikasi/periksa ulang dengan metode trianglasi terhadap sumber data. Dimana kami membandingkan data hasil pengamatan dengan data yang kami dapat dari hasil wawancara dan diskusi kelompok. Selain itu, kami juga mencoba mengomparasikan berbagai variasi yang muncul antara perspektif seseorang dengan yang lainnya. Kesemua proses ini dilakukan secara transparan dan terbuka dengan kolaborasi para pemangku kepentingan. 
JPPM (Jurnal Pendidikan dan Pemberdayaan Masyarakat), 8 (1), 2021 - 35

Agung Yoga Asmoro, Firdaus Yusrizal, Indra Saputra

\section{HASIL DAN PEMBAHASAN}

\section{Kondisi Lingkungan Desa Sekapuk}

Desa Sekapuk terletak di wilayah administratif Kecamatan Ujungpangkah Kabupaten Gresik yang berada di sebelah utara Ibukota Kabupaten Gresik. Desa Sekapuk berbatasan wilayah dengan sebelah utara berbatasan dengan Desa Gosari, Kecamatan Ujungpangkah; Sebelah selatan berbatasan dengan Desa Daudo, Kecamatan Panceng; Sebelah timur berbatasan dengan Desa Bolo/Wadeng, Kecamatan Ujungpangkah/Sidayu; dan Sebelah barat berbatasan dengan Desa Wotan, Kecamatan Panceng. Ditinjau dari posisi geografisnya, Desa Sekapuk berada pada $6^{\circ}{ }_{5} 6^{\prime} 58.45^{\prime \prime}$ lintang selatan dan $112^{\circ} 30^{\prime} 23.03^{\prime \prime}$ bujur timur.

Luas wilayah Desa Sekapuk menurut penggunaannya terdiri atas: Tanah kering berupa Tegal/Ladang dengan luas 147.7 hektar; Pemukiman seluas 52.651 hektar; dan Pekarangan seluas 11.6 hektar. Total Luas adalah 211.951 hektar.

Profil masyarakat Desa Sekapuk terdiri dari penduduk laki-laki sejumlah 2324 orang; perempuan 2349 orang; sehingga total penduduk Desa Sekapuk berjumlah 4673 orang, yang terbentuk dari 1257 kepala keluarga. Pekerjaan masyarakat Desa Sekapuk umumnya adalah sebagai petani, buruh migran, pedagang keliling, penambang batu kapur mekanik, penambang batu kapur manual, dan juragan batu kapur, sementara jumlah kecil lainnya berprofesi sebagai PNS, pensiunan TNI/Polri, Dokter, Bidan/Perawat, dan profesi lainnya. Mayoritas penduduk Desa Sekapuk beragama Islam. Landasan legal pembangunan kepariwisataan di tingkat Desa Sekapuk tertuang dalam Rancangan Peraturan Desa Sekapuk Nomor o6 Tahun 2018 Tentang Rencana Pembangunan Kepariwisataan Desa Sekapuk.

\section{Pariwisata Berbasiskan Masyarakat (Community-Based Tourism)}

Secara global, usaha kecil dan menengah mendominasi sektor ekonomi pariwisata (Jammu dkk., 2020; Ravindra Deyshappriya, 2020). CBT merupakan salah satu bentuk pariwisata yang mengupayakan pemberdayaan masyarakat dalam pengelolaan pertumbuhan pariwisata dan mencapai aspirasi masyarakat terkait dengan kesejahteraannya, termasuk didalamnya adalah pembangunan ekonomi, sosial dan lingkungan secara berkelanjutan (The ASEAN Secretariat, 2016, hlm. 2). Oleh karena itu, CBT tidak hanya melibatkan kemitraan antara bisnis pariwisata dan komunitas untuk memberikan manfaat bagi keduanya, tetapi juga melibatkan dukungan komunitas (dan eksternal) untuk usaha kecil pariwisata, yang pada gilirannya berkomitmen untuk memberikan dukungan untuk proyek komunitas yang meningkatkan kesejahteraan kolektif (Baniya, dkk., 2018).

CBT melakukan pemberdayaan terhadap masyarakat setempat di dalam menentukan masa depan sosio-ekonomi mereka melalui aktivitas jasa berbayar yang biasanya: menghadirkan dan merayakan tradisi dan gaya hidup lokal; melestarikan sumber daya alam dan budaya; dan mendorong interaksi tuan rumah-tamu yang adil dan saling menguntungkan. CBT didefinisikan sebagai kegiatan pariwisata yang dimiliki dan dioperasikan oleh masyarakat, dan dikelola atau dikoordinasikan di tingkat masyarakat yang berkontribusi pada kesejahteraan masyarakat melalui mendukung mata pencaharian yang berkelanjutan dan melindungi nilai tradisi sosial budaya dan sumber daya warisan alam dan budaya (Mtapuri \& Giampiccoli, 2019).

Berdasarkan definisi di atas, CBT memiliki prinsip-prinsip: 1) Melibatkan dan memberdayakan masyarakat untuk memastikan kepemilikan dan pengelolaan yang transparan; 2) Menjalin kemitraan dengan pemangku kepentingan terkait;3) Mendapatkan kedudukan yang diakui dengan otoritas terkait; 4) Meningkatkan kesejahteraan sosial dan memelihara martabat manusia; 5) Mencakup yang adil dan transparan mekanisme pembagian manfaat; 6) Meningkatkan hubungan dengan ekonomi lokal dan regional; 7) Menghormati budaya dan tradisi lokal; 8) Berkontribusi pada konservasi sumber daya alam; 9) Meningkatkan kualitas pengalaman pengunjung dengan memperkuat interaksi tuan rumah dan tamu yang bermakna; dan 10) Bekerja menuju kemandirian finansial (The ASEAN Secretariat, 2016:2). 
JPPM (Jurnal Pendidikan dan Pemberdayaan Masyarakat), 8 (1), 2021 - 36

Agung Yoga Asmoro, Firdaus Yusrizal, Indra Saputra

Tabel 2. Evaluasi CBT di Desa Sekapuk

\begin{tabular}{|c|c|c|c|c|c|c|}
\hline \multirow{2}{*}{ Kriteria } & \multirow{2}{*}{ Indikator } & \multicolumn{5}{|c|}{ Skala } \\
\hline & & 1 & 2 & 3 & 4 & 5 \\
\hline Partisipasi dan pemberdayaan masyarakat & $\begin{array}{l}\text { Kualitas, kuantitas pemberdayaan } \\
\text { masyarakat }\end{array}$ & & & & $\sqrt{ }$ & \\
\hline Kemitraan dengan pemangku kepentingan terkait & Jumlah, jenis, model kemitraan & & & & $\sqrt{ }$ & \\
\hline Pengakuan dari otoritas terkait & Bentuk pengakuan & & & & $\sqrt{ }$ & \\
\hline $\begin{array}{l}\text { Peningkatan kesejahteraan sosial dan pemeliharaan } \\
\text { martabat manusia }\end{array}$ & Kegiatan kesejahteraan masyarakat & & & & $\sqrt{ }$ & \\
\hline $\begin{array}{l}\text { Mekanisme yang adil dan transparan dalam } \\
\text { pembagian manfaat }\end{array}$ & $\begin{array}{l}\text { Keterbukaan informasi pengelolaan } \\
\text { keuangan }\end{array}$ & & & & $\sqrt{ }$ & \\
\hline $\begin{array}{l}\text { Peningkatan hubungan dengan ekonomi lokal dan } \\
\text { regional }\end{array}$ & Ragam asal kunjungan wisatawan & & & & $\sqrt{ }$ & \\
\hline Penghormatan budaya dan tradisi lokal & Perwujudan budaya/tradisi di DTW & & & $\sqrt{ }$ & & \\
\hline Kontribusi terhadap konservasi sumber daya alam & Bentuk kegiatan konservasi & & $\sqrt{ }$ & & & \\
\hline Peningkatan kualitas pengalaman pengunjung & $\begin{array}{l}\text { Elemen non fisik dari } \\
\text { atraksi/aktivitas }\end{array}$ & & & $\sqrt{ }$ & & \\
\hline Kemandirian finansial & Keuntungan, pendapatan & & & & $\sqrt{ }$ & \\
\hline
\end{tabular}

\section{Wisata Setigi sebagai CBT Desa Sekapuk}

Kami melihat bahwa wisata Setigi adalah perwujudan nyata dari CBT di Desa Sekapuk. Semula area ini merupakan lahan penambangan kapur PT Polowijo Gosari. Namun, semenjak tidak lagi ditambang pada 2003, bukit kapur seluas lima (5) hektar telah menjelma menjadi tempat pembuangan sampah warga Desa Sekapuk. Ini mengakibatkan pemandangan tak sedap dan kumuh. Bahkan, wilayah ini sudah dipenuhi sampah yang tingginya hingga melebihi batas jalan. Dengan inisiatif dari seorang tokoh masyarakat, yang juga seorang Kepala Desa, pada tahun 2018 lahan ini akhirnya dibersihkan dan selanjutnya direklamasi secara gotong royong dengan keterlibatan ratusan masyarakat setempat menjadi objek wisata bertajuk geo wisata karst yang bernilai edukasi dan cocok untuk semua kalangan. Sebagaimana yang disampaikan oleh Kepala Desa Sekapuk:

"Pasca tambang setelah sampah-sampah sudah dibersihkan dan akan dilakukan pembangunan jembatan peradaban, danau serta air terjunnya, sekaligus rumah apung, rumah adat, sarpras, sekaligus taman - taman dan pagar keliling nya." (Abdul Halim, 2020)

Kegiatan reklamasi mengonversi lahan bekas tambang batu gamping, yang sempat belasan tahun (2003-2018) menjadi tempat pembuangan akhir, menjadi sebuah daya tarik wisata akhirnya rampung pada bulan Mei 2018, dan dibuka (soft-opening) pada tanggal 7 mei 2018 dengan nama Wisata Setigi.

Berdasarkan hasil diskusi bersama pemangku kepentingan kami menyadari bahwa Daya tarik wisata (DTW) yang dimiliki oleh warga masyarakat Desa Sekapuk, dan dikelola oleh Badan Usaha Masyarakat Desa Sekapuk (Bumdes), kini menjelma menjadi salah satu DTW unggulan yang dimiliki oleh Kabupaten Gresik, Jawa Timur. Dimana ide dasar Wisata Setigi adalah membangun sebuah DTW alam untuk memenuhi selera pengunjung akan aktivitas swafoto dan swavideo. Aktivitas swafoto dan swavideo ini tidak terlepas dari kemajuan perkembangan dunia digital khususnya terkait dengan berbagai aplikasi media sosial dan media berbagi (sharing apps) seperti instagram, facebook, tiktok, dan semacamnya. Variasi lansekap dan kontur bukit kapur yang unik, ditunjang dengan puluhan wahana/atraksi buatan semakin memberikan pilihan kepada pengunjung dalam beraktivitas wisata swafoto dan swavideo. Keunikan ini juga mampu menarik minat para pengunjung yang membutuhkan setting lokasi pemotretan untuk kebutuhan prewedding. Harga tiket yang relatif terjangkau ( $\mathrm{Rp} 15.000$ per pengunjung umum) terbukti cukup menjadi salah satu faktor kompetitif untuk mampu menarik minat pengunjung asal luar Kabupaten Gresik untuk berwisata ke Setigi.

Wisata Setigi berlokasi $35 \mathrm{~km}$ dari pusat ibukota Kabupaten Gresik, dan $53 \mathrm{~km}$ dari Kota Surabaya. Akses menuju Setigi dipersingkat dengan ketersediaan akses jalan tol yang mencapai pintu tol Manyar. Dari sini, perjalanan menuju Setigi hanya membutuhkan waktu 40 menit (26 km). Dari akses jalan utama (Jalan Daendels) menuju lokasi Setigi hanya berjarak 900 meter. 
Hasil observasi lapangan menunjukkan bahwa Setigi memadukan keindahan kontur alam bukit kapur bekas pertambangan yang memiliki nilai estetika tersendiri dengan dua puluh empat (24) spot atraksi buatan yang sengaja didisain dan dibangun untuk memenuhi kebutuhan dan keinginan pengunjung akan spot-spot yang instagramable guna aktivitas swafoto pengunjung. Atraksi tersebut adalah: Tangga Derajat, Lorong Kuliner, Watu Jodoh, Mushola Persia, Monumen Setigi, Candi Topeng Nusantara, Pahatan Nogo Puspo, Topeng Suku Asmat, Kampung Bambu, Panggung Batu, Goa Karst, Goa Pancawarna, Semar dan Pitutur, Danau Buatan, Wahana Air, Air Terjun, Jembatan Peradaban, Rumah Apung, Rumah Adat, Nogo Giri Pancoran, Gopala dan Dwarapala, Gerbang Ghoib, Goa Emas, dan Taman Desa.

Adapun, dari hasil wawancara dengan wisatawan, kami temukan bahwa fasilitas wisata atau amenities di Setigi memainkan peran penting dalam membentuk pengalaman pengunjung. "Meski masih terus dalam proses pembangunan beberapa fasilitas dan sarananya, tapi lumayan bisa dinikmati keindahannya."

Beberapa fasilitas wisata yang tersedia di Setigi diantaranya adalah gerbang masuk utama, Pusat Informasi Wisata dengan penyediaan jasa pemandu wisata, fasilitas makan minum yang dilengkapi dengan konektivitas internet (30 stand kuliner di Pasar Kuliner, King Coffee BPD dan cafe Pokdarwis), fasilitas lima belas (15) gazebo sebagai sarana istirahat pengunjung, empat (4) lokasi toilet reguler dan satu (1) toilet VIP, transportasi berupa kendaraan operasional Setigi, fasilitas parkir untuk kendaraan pengunjung, pendopo, mushola (tersedia dua (2) aktual dan satu (1) dalam progress pembangunan), kedai cinderamata, dan beberapa interpretasi penunjuk arah ke lokasi atraksi juga tersedia.

Dengan rata-rata 16.ooo pengunjung per bulan, Setigi berpotensi menjadi sebuah destinasi wisata unggulan. Ditinjau secara geografis, Setigi didominasi oleh pengunjung dari Kabupaten Gresik, Lamongan, dan Surabaya. Namun demikian, jumlah pengunjung dari daerah asal yang cukup jauh seperti Kabupaten Malang dan Pacitan juga tercatat pernah berkunjung ke Setigi. Selain pengunjung domestik, dalam beberapa kesempatan juga tercatat kunjungan dari wisatawan mancanegara, khususnya warga negara dari Amerika Serikat, Kanada, Perancis, Australia, Belanda, Thailand, Korea Selatan, Singapura dan Malaysia.

\section{Partisipasi dan Pemberdayaan Masyarakat}

Berdasarkan hasil diskusi kelompok ditemukan bahwa partisipasi dan pemberdayaan masyarakat terkait dengan CBT Desa Sekapuk bisa ditinjau dari sebelum dan setelah Daya Tarik Wisata (DTW) Setigi beroperasi. Pada 2018, di saat Setigi masih berupa lahan pembuangan akhir, ratusan masyarakat setempat bergotongroyong untuk membersihkan dan mereklamasi lahan menjadi DTW Setigi yang kita ketahui sekarang. Hal ini selaras dengan indikator keefektivitasan pemberdayaan masyarakat yang digagas oleh (Cerreta \& Giovene di Girasole, 2020; Morrissey, 2000) yang berpendapat bahwa salah satu syarat awal dari partisipasi masyarakat yang baik adalah dengan melibatkan masyarakat semenjak tahapan perencanaan, dan juga menurutsertakannya dalam tahapan pelaksanaan.

Tidak hanya itu, modal pembangunan DTW Setigi juga sebagian besar berasal dari masyarakat Desa Sekapuk dengan struktur modal berupa saham yang diperoleh dari Tabungan plus investasi (Taplus Inves). Program taplus invest yang digagas dan dijalankan oleh aparat Desa Sekapuk melalui Bumdes Sekapuk dengan menjual obligasi 853 lembar saham Setigi kepada masyarakat Desa Sekapuk, memiliki dampak psikososial yang positif. Dengan valuasi Rp 2.400.0oo per saham, yang diperoleh dari masyarakat dengan program cicilan $\mathrm{Rp}$ 8.ooo per hari, maka terkumpul total dana kurang lebih dua $\mathrm{Rp} 2$ miliar, yang dengan ditambah $\mathrm{Rp} 1$ miliar dana dari Kas Desa, menjadikan total modal kas Setigi sebesar Rp 3 miliar. Ini berarti, secara kepemilikan, Setigi merupakan destinasi wisata yang dimiliki oleh warga setempat. Fakta ini dengan sendirinya menumbuhkan rasa kepemilikan warga yang tinggi terkait dengan keberadaan Setigi.

Setelah dibuka resmi (grand opening) pada Januari 2020, partisipasi dan pemberdayaan masyarakat bahkan lebih signifikan. Keberadaan 120 warga yang merupakan perwakilan dari 


\section{JPPM (Jurnal Pendidikan dan Pemberdayaan Masyarakat), 8 (1), 2021 - 38}

Agung Yoga Asmoro, Firdaus Yusrizal, Indra Saputra

setiap RT di wilayah Desa Sekapuk yang terbagi ke dalam tiga puluh (30) penjual stand kuliner di fasilitas Pasar Kuliner, memberikan dampak ekonomi langsung kepada sebagian masyarakat setempat. Juga keberadaan empat puluh tujuh (47) karyawan Setigi yang keseluruhannya merupakan warga asal Desa Sekapuk secara praktis turut pula berkontribusi terhadap peningkatan perekonomian warga setempat.

Selain memberdayakan masyarakat setempat sebagai tenaga kerja di Wisata Setigi, Kepala Desa Sekapuk juga membentuk suatu organisasi Pokdarwis Pelangi (Kelompok Sadar Wisata) dengan pertimbangan untuk membantu kinerja Bumdes. Pokdarwis Pelangi ini merupakan bagian dari masyarakat secara swadaya untuk membantu tercapainya kepariwisataan yang lebih baik.

\section{Kemitraan dengan Pemangku Kepentingan Terkait}

Pemangku kepentingan adalah individu atau kelompok yang dapat diidentifikasi yang dipengaruhi oleh, atau dapat mempengaruhi, pencapaian tujuan perusahaan (Freeman, 2015), sementara pemangku kepentingan pariwisata dapat dikatakan sebagai suatu kelompok antar organisasi atau individu untuk mengelola dan menyelesaikan masalah dan isu yang berkaitan dengan promosi dan strategi pariwisata (Islam \& Al-Amin, 2019). Lebih rincinya, pemangku kepentingan pariwisata dapat dilihat dari pendekatan Penta Helix, yang terdiri dari unsur akademisi, pebisnis, komunitas, pemerintah, dan media (Sutono, 2020:12).

Kemitraan CBT Sekapuk dengan pemangku kepentingan pariwisata selama ini terjalin dengan amat baik. Di mana kemitraan dengan unsur akademisi semenjak diresmikannya Wisata Setigi telah menghasilkan sejumlah artikel penelitian maupun skripsi, diantaranya: penelitian tentang pengelolaan keuangan Bumdes (Mayasari, 2019); kajian tentang investasi masyarakat (Nasibah, 2019); studi tentang sistem informasi (Fidihama, 2019); strategi pengembangan destinasi wisata (Asmoro \& Aziz, 2020); studi yang melihat tentang pemanfaatan lahan (Wardhana dkk., 2020); dan penelitian tentang pemasaran (Jannah, 2019).

Kemitraan dengan sektor bisnis telah terjalin dengan pihak Biro Perjalanan Wisata dari beberapa kota seperti Gresik, Lamongan, Surabaya, dan Malang yang dari bentuk kemitraan ini menghasilkan kunjungan ulang cukup tinggi. Kemitraan dengan komunitas-komunitas telah pula terjalin dengan cukup baik, diantaranya adalah komunitas yang berlatarbelakang pendidikan seperti sekolah berbagai jenjang, maupun komunitas-komunitas non formal seperti: komunitas otomotif, komunitas olahraga, dan lain sebagainya. Kemitraan dengan unsur pemerintah telah terjalin pada semua tingkat pemerintahan. Mulai dari tingkat desa, dimana inisiator dari CBT Sekapuk adalah juga seorang Kepala Desa, tingkat Kabupaten, dimana kemitraan ini ditandai dengan dukungan dari Dinas Pariwisata untuk dalam penanaman bibit pohon, dijadikannya Wisata Setigi sebagai DTW percontohan yang mendapat ijin dibuka pertama kali oleh Bupati, dukungan dari Pemprov Jatim, dimana Gubernur Jatim hadir langsung ke Desa Sekapuk dalam rangka peringatan Hari Anak Nasional, sekaligus memberikan bantuan dana sebesar Rp5o juta.

Salah satu kekuatan terbesar Desa Sekapuk adalah kemitraan erat yang terjalin antara Kepala Desa Sekapuk sebagai pemrakarsa sekaligus penanggung jawab CBT dengan pihak media. Hal ini bisa diamati dari frekuensi publikasi yang tinggi pada media massa maupun media sosial yang turut berkontribusi terhadap kunjungan pengunjung ke Setigi. Sampai dengan saat ini tercatat tidak kurang dari 8 (delapan) publikasi televisi nasional dan regional pernah menayangkan Setigi di dalam berbagai program acara. Sementara publikasi media cetak lebih sering mengangkat keunikan dan keindahan wisata Setigi, khususnya media cetak dengan ruang lingkup regional Jawa Timur.

\section{Pengakuan dari Otoritas Terkait}

Pengakuan dari otoritas terkait merupakan salah satu prasayarat penilaian kesuksesan dari pengelolaan CBT (The ASEAN Secretariat, 2016:2). Keberhasilan Desa Sekapuk dalam mengembangkan CBT di Setigi ini mendapatkan pengakuan dari berbagai otoritas terkait. 


\section{JPPM (Jurnal Pendidikan dan Pemberdayaan Masyarakat), 8 (1), 2021 - 39}

Agung Yoga Asmoro, Firdaus Yusrizal, Indra Saputra

Otoritas dalam tingkat desa, hal ini sudah merupakan keniscayaan mengingat DTW Setigi merupakan inisiatif dari tokoh masyarakat yang juga merangkap sebagai seorang Kepala Desa. Sehingga keberadaan DTW Setigi ini termuat dalam Perkades Sekapuk, dan pengelolaannya dilakukan oleh Bumdes Sekapuk.

Pada tingkat kabupaten, pengakuan ini bisa dilihat dari ditetapkannya Setigi sebagai DTW yang menjadi prioritas pada saat kepariwisataan di Kabupaten Gresik dibuka kembali pada periode "new normal" (TribunNews.com, 2020c). Pengakuan pada tingkat provinsi terlihat pada saat Gubernur Jawa Timur melakukan kunjungan resmi ke DTW Setigi dalam rangka Hari Anak Nasional 2020 (Kompas.com, 2020; TribunNews.com, 2020b).

Pengakuan pada tingkat nasional diterima oleh Setigi berupa dukungan dari Anggota Komisi X DPR-RI yang mendukung upaya Desa Sekapuk untuk berkompetisi pada kompetisi pariwisata nasional dan juga membuka kembali DTW Setigi pada periode "new normal" (TribunNews.com, 2020a), sekaligus ditegaskan dengan turut hadir langsung bersama dengan Gubernur Jawa Timur saat perayaan Hari Anak Nasional yang diselenggarakan di Setigi (InfoPublik.id, 2020).

\section{Peningkatan Kesejahteraan Sosial dan Pemeliharaan Martabat Manusia}

Berdasarkan hasil temuan bahwa dalam upaya peningkatan kesejahteraan sosial dan pemeliharaan martabat manusia sebagaimana prinsip ke-4 dari CBT (The ASEAN Secretariat, 2016:2), Bumdes Sekapuk selaku pengelola Wisata Setigi turut berkontribusi terhadap program pemberian beasiswa pendidikan, dimana warga masyarakat berhak mendapatkan fasilitas pendidikan gratis hingga tahapan sarjana dengan beberapa kriteria tertentu, yaitu: berlaku bagi anak yatim/piatu dan para penghapal Al-Qur'an. Bagi anak yatim/piatu, mereka mendapatkan beasiswa pendidikan sejak kelas I SD hingga lulus SMP. Sementara bagi penghapal Al-Qur'an mendapatkan beasiswa hingga lulus Sarjana tak terkecuali jurusan Fakultas Kedokteran. Dana beasiswa ini berasal dari gabungan PADes dan kas Bumdes.

Selain beasiswa, upaya peningkatan kesejahteraan sosial bisa dilihat dari diberikannya akses kepada 120 perwakilan masyarakat untuk menjajakan kuliner di dalam Pasar Kuliner Wisata Setigi. Warga Desa Sekapuk, mendapatkan fasilitas akses masuk ke kawasan secara gratis, hanya dengan menunjukkan KTP. Khusus bagi warga Desa Sekapuk yang masih berstatuskan pelajar, mendapatkan kesempatan untuk menggunakan fasilitas koneksi WIFI gratis yang mereka gunakan saat program belajar mandiri dari rumah dijalankan. Upaya lain yang dilakukan oleh Bumdes Sekapuk terkait dengan peningkatan kesejahteraan sosial dapat dilihat pada adanya program pinjaman lunak untuk berusaha kepada janda-janda yang merupakan warga Desa Sekapuk dengan tingkat bunga relatif rendah, sebesar 9\%/tahun (Fitrianto, 2019).

\section{Mekanisme yang Adil dan Transparan dalam Pembagian Manfaat}

Azas transparansi dalam pengelolaan keuangan merupakan prinsip CBT berikutnya (Suwanna \& Chaikasem, 2018; The ASEAN Secretariat, 2016:2). Dalam hal ini transparansi pengelolaan keuangan yang dilakukan oleh Wisata Setigi kepada masyarakat yang terlibat sebagai investor dilakukan secara profesional. Mekanisme pembagian manfaat dilakukan dengan pelaporan keuangan di akhir tahun (tutup buku) pada saat Rapat Umum Pemegang Saham. Sejauh ini jumlah saham yang diterbitkan adalah 789 lembar saham dan 64 lembar saham tambahan (Nasibah, 2019) sehingga berjumlah 853 lembar dengan total valuasi Rp 2.047.200.0oo. Adapun, laporan bulanan rutin dilaporkan melalui mekanisme rapat desa yang dihadiri oleh perwakilan dari 29 RT, dimana Bumdes menyampaikan laporan terkait dengan arus kas bulanan.

Kepemilikan saham masyarakat dalam Wisata Setigi ini sedari awal bersifat sukarela, di mana tidak ada unsur paksaan terhadap masyarakat. Bumdes sebagai pengelola di awal tahun mempresentasikan rencana kerja, mekanisme, serta proyeksi keuntungan yang mungkin diterima oleh masyarakat selaku pemegang saham, dimana proyeksi keuntungan berada pada 
JPPM (Jurnal Pendidikan dan Pemberdayaan Masyarakat), 8 (1), 2021 - 40

Agung Yoga Asmoro, Firdaus Yusrizal, Indra Saputra

kisaran angka 25\% per tahunnya, dengan rasio bagi hasil 6o:40. Keuntungan usaha ini selanjutnya akan dibagikan setelah Rapat Umum Pemegang Saham di awal tahun berikutnya. Mekanisme pengelolaan keuangan Bumdes selayaknya Perseroan Terbatas ini diyakini oleh pengelola sebagai jalan keluar terbaik di dalam mengelola CBT di Desa Sekapuk.

\section{Peningkatan Hubungan dengan Ekonomi Lokal dan Regional}

Peningkatan jumlah kunjungan wisatawan berpengaruh positif dan signifikan terhadap pertumbuhan ekonomi lokal (Wang, 2020) dan regional (Amnar, 2017; Sacco \& Cassar, 2019). Penerimaan ekonomi dapat mendorong konsumsi komersial, mempercepat pertumbuhan ekonomi, dan juga meningkatkan industri terkait lainnya.

Semenjak resmi beroperasi (grand opening) pada awal 2020, Setigi sebagai CBT Desa Sekapuk telah menerima puluhan ribu pengunjung.

Tabel 3. Jumlah Pengunjung Setigi Tahun 2020

\begin{tabular}{cccccccc}
\hline & Januari & Februari & Maret $\left.{ }^{*}\right)$ & April $\left.^{*}\right)$ & Mei *) & Juni & Juli \\
\hline Pengunjung & 19.606 & 11.280 & 14.530 & o & o & 20.217 & 13.693 \\
\hline
\end{tabular}

Sumber: Bumdes Setigi, 2020

*) Catatan Maret sampai dengan tanggal 15; selebihnya tutup akibat pandemi covid-19

Pengunjung berasal dari berbagai daerah, mayoritas berasal dari Kabupaten/Kota yang secara geografis berdekatan dengan Desa Sekapuk seperti Gresik, Lamongan, dan Surabaya. Namun demikian, terdapat pula pengunjung yang datang dari jauh seperti Malang, Pacitan, bahkan mancanegara. Upaya peningkatan kunjungan ini dilakukan oleh pengelola Bumdes Sekapuk dengan program-program pemasaran kepada beberapa target. Untuk pengunjung lokal, pengelola melakukan pendekatan dan upaya pemasaran kepada pihak-pihak institusi pendidikan (sekolah) baik dari tingkat paling bawah (TK) hingga ke Universitas untuk menjadikan Setigi sebagai lokasi wisata edukasi, sekaligus laboratorium alam tentang formasi geologi terutama karst dan batuan kapur (Wardhana dkk., 2020). Kepada target dari daerah yang jauh, pengelola memanfaatkan teknologi informasi dan media sosial, untuk dapat menarik minat kunjungan wisatawan.

\section{Penghargaan terhadap Budaya dan Tradisi Lokal}

Pariwisata memberikan dampak terhadap kebudayaan secara positif maupun negatif. Dampak positif diantaranya dengan berkembangnya sistem pengetahuan masyarakat lokal, munculnya mata pencaharian baru, mengenal keragaman bahasa, kemajuan teknologi, dan pembentukan organisasi sosial (Pratiwi \& Pinasti, 2017). Selain itu juga bisa dilihat pada terlestarikannya budaya masyarakat lokal seperti tari-tarian adat, sejarah, berbagai bangunan bersejarah (Swesti, 2019). Sementara dampak negatif yang bisa terjadi seperti terjadinya tekanan tambahan penduduk akibat pendatang baru dari luar daerah; timbulnya komersialisasi budaya; berkembangnya pola hidup konsumtif; terganggunya lingkungan; semakin terbatasnya lahan pertanian; pencernaan budaya; dan terdesaknya masyarakat setempat (Spillane, 1989:47) dalam (Khairiah, 2009).

CBT meletakkan penghormatan terhadap budaya dan tradisi lokal sebagai salah satu prinsipnya (The ASEAN Secretariat, 2016:2), yang mana dalam konteks ini, CBT Desa Sekapuk melalui Bumdes sebagai pengelola Setigi masih memiliki ruang peningkatan. Sejauh ini secara visual penghargaan terhadap budaya dan tradisi lokal di Setigi bisa diamati dari pola desain tradisional pada gazebo, dan beberapa wahana dengan tema tradisional semacam Candi Topeng Nusantara, Pahatan Nogo Puspo, Kampung Bambu, Panggung Batu, Semar dan Pitutur, Rumah Apung, Rumah Adat, Nogo Giri Pancoran, Gopala dan Dwarapala. Walau disaat yang sama juga menampilkan visualisasi budaya non-lokal semacam Topeng Suku Asmat dan Mushola Persia. Adapun menu makanan tradisional khas masyarakat setempat sudah disajikan kepada pengunjung di pasar kuliner. 
Pengelola perlu mempertimbangan pengembangan model bisnis industri pariwisata budaya dengan mengembangkan ruang pengalaman budaya yang komprehensif dengan mengandalkan ruang budaya tradisional, mengembangkan industri pertunjukan budaya dan pariwisata yang melibatkan pertunjukan seni dan sumber daya wisata, mengembangkan industri budaya dan kreativitas dengan cinderamata yang berorientasi wisata, dan mengembangkan industri hiburan yang melibatkan pertunjukan budaya bertema (ChaoZhi \& MinMin, 2020).

\section{Berkontribusi terhadap Konservasi Sumber Daya Alam}

Konservasi adalah upaya pelestarian keanekaragaman kehidupan di bumi dengan melindungi tanah dan air yang dibutuhkan untuk bertahan hidup (Björk, dkk., 20o8) yang dalam implementasinya mengintegrasikan aspek ekologi, sosiologi, antropologi, ilmu politik, ekonomi dan disiplin lain dalam perencanaan konservasi (Leenhardt, et al., dalam Syukur, 2016). Kontribusi terhadap konservasi sumber daya alam merupakan prinsip utama dari CBT (The ASEAN Secretariat, 2016:2).

Wisata Setigi sebagai sisa lahan bekas penambangan kapur yang berlokasi di sebelah kawasan penambangan kapur aktif jelas terdampak secara ekologis baik secara biotik dan abiotik. Dampak biotik adalah manusia berupa terganggunya saluran pernapasan akibat debu dan asap pembakaran, berkurangnya vegetasi yang berimbas kepada kerusakan lingkungan, dan terganggunya kelestarian fauna karena kerusakan ekosistem. Sementara dampak terhadap unsur abiotik berupa berubahnya sifat fisik, kimia dan biologi tanah (Gofur \& Wesnawa, 2018).

Upaya merubah sisa penambangan yang sempat menjadi tempat pembuangan sampah tidak serta merta dapat dianggap sebagai suatu upaya konservasi. Untuk mengembalikan fungsi ekologis Setigi kembali menjadi bentuk semula sebelum periode penambangan, pengelola perlu melakukan berbagai upaya restorasi dan rehabilitasi untuk memulihkan lahan di Setigi ke bentuknya semula sebelum masa penambangan. Tahap pertama tentunya dengan mengidentifikasi ekosistem awal di Desa Sekapuk, sehingga program penghijauan/reboisasi yang selanjutnya dilakukan akan mendekati bentuk ekosistem awal.

Sebagaimana yang dikemukakan Fitrianto (2019) bahwa Bumdes selaku pengelola perlu memiliki visi keberlanjutan lingkungan, dengan memperhatikan aspek daya dukung lingkungan serta kualitas lingkungan. Ini dilakukan dengan upaya penghijauan untuk memperindang dan sebagai upaya rehabilitasi lahan. Namun demikian, patut pula diapresiasi langkah pengelola yang sudah mengadopsi prinsip daur ulang sampah plastik model kemitraan dengan masyarakat yang berprofesi sebagai pengepul sampah.

\section{Peningkatan Kualitas Pengalaman Pengunjung dengan Penguatan Interaksi Tuan Rumah dan Tamu Yang Bermakna}

Interaksi aktual antara pengunjung dan warga masyarakat selaku tuan rumah di Setigi secara berurutan terjadi di Gerbang masuk kawasan wisata, di mana pengunjung harus membayar tiket masuk dan melalui serangkaian prosedur protokol pencegahan covid-19; selanjutnya, pada area parkir dimana interaksi terjadi antara pengunjung dengan petugas parkir; interaksi selanjutnya terjadi pada wahana wisata, dimana interaksi tercipta antara pengunjung dengan petugas yang bertanggungjawab di area tersebut; interaksi lain terjalin pada saat pengunjung sedang beristirahat makan di Pasar Kuliner; di toilet, pada Pusat Informasi wisata, dan Toko cinderamata.

Secara umum dapat dikatakan bahwa pengalaman kunjungan yang dirasakan oleh wisatawan di Setigi belum maksimal dan masih tersedia banyak ruang peningkatan. Walau interaksi antara tamu dan masyarakat setempat sudah terjalin, namun pengelola seyogianya perlu mempertimbangkan keberlanjutan produk-produk CBT seperti: menyediakan tur dan aktivitas wisata desa yang dikelola dengan kualitas tinggi, melakukan kolaborasi dan kerja sama dengan desa tetangga dan mengintegrasikannya ke dalam satu paket pemasaran. Selain itu, perlu juga disampaikan informasi lingkungan dan budaya termasuk juga interpretasi akan masyarakat dan sekitarnya. 


\section{JPPM (Jurnal Pendidikan dan Pemberdayaan Masyarakat), 8 (1), 2021 - 42}

Agung Yoga Asmoro, Firdaus Yusrizal, Indra Saputra

Aturan terkait dengan keselamatan dan keamanan pengunjung perlu disajikan secara visual pada area-area yang memiliki resiko tinggi. Hal-hal yang terkait pemberikan informasi yang akurat dalam program pemasaran, sistem kendali mutu termasuk upaya mendapatkan umpan balik pengunjung, serta diberikannya peluang bagi pengunjung untuk berkontribusi pada kegiatan lokal bersama-sama anggota masyarakat, sebaiknya sudah dipertimbangkan oleh Bumdes Sekapuk untuk dijalankan pada masa yang akan datang (The ASEAN Secretariat, 2016).

\section{Bekerja Menuju Kemandirian Finansial}

Sampai dengan tahun 2017, Desa sekapuk masih tercatat sebagai daerah tertinggal dengan tingkat pendapatan rata-rata penduduk sebesar Rp 1.80o.ooo,-/bulan (Fitrianto, 2019). Hal ini cukup ironis mengingat Kabupaten Gresik adalah salah satu Kabupaten dengan UMK tertinggi di Jawa Timur dengan besaran Rp 4.197.030,51 per bulan (Keputusan Gubernur Jatim No. 568 Th 2019 tentang UMK Jatim Th 2020, 2019).

Penduduk Sekapuk yang sebagian besar mata pencaharian penduduknya bertani di ladang dengan pengairannya bergantung pada air hujan Di sela-sela menunggu hujan datang, masyarakat juga bekerja membuat batu bata di pegunungan Sekapuk. Keberadaan Setigi terbukti mampu menyerap 47 tenaga kerja yang berasal dari warga setempat dengan standar gaji minimal sebesar $15 \%$ di atas rata-rata penghasilan warga Desa Sekapuk umumnya, sekaligus memberikan kesempatan kerja bagi Ibu-Ibu RT dalam menjajakan makanan di Pasar Kuliner.

Terdapat 30 stan di Pasar Kuliner yang melibatkan 120 tenaga kerja. Keberadaan Setigi jelas secara langsung sudah memberikan dampak ekonomi kepada setidaknya 167 orang. Dimana jika mengacu aplikasi penghitungan dampak berganda pariwisata dengan pendekatan keynesian local income multiplier $(1,64)$ dan ratio income multiplier $(2,46)$ (Putra dkk., 2017) yang menunjukkan besaran dampak langsung yang dirasakan dari pengeluaran wisatawan yang berdampak langsung pada keseluruhan ekonomi lokal. Menandakan kemanfaatan Setigi bisa dirasakan oleh 274-410 warga masyarakat atau sekitar 6-9\% dari keseluruhan warga Desa Sekapuk. Seiring dengan semakin meningkatnya kunjungan wisatawan ke Setigi, maka penerimaan masyarakat setempat di masa yang akan datang juga akan meningkat pula.

\section{SIMPULAN}

Pada dasarnya dapat dikatakan bahwa implementasi CBT di Desa Sekapuk sudah berada dalam koridor prinsip-prinsip CBT. Hal ini terlihat dari tingginya partisipasi dan pemberdayaan masyarakat dalam kepemilikan DTW Setigi dan dijalankannya pengelolaan DTW secara transparan melalui Bumdes; Kemitraan dengan pemangku kepentingan terkait sudah terjalin dengan baik. Selain itu, Wisata Setigi sebagai sebuah CBT dari Desa Sekapuk sudah mendapatkan kedudukan yang diakui oleh otoritas terkait, baik dari tingkatan terendah yaitu Desa, Kabupaten, Provinsi, bahkan sudah pula masuk radar di tingkat nasional. Kontribusi CBT Sekapuk terhadap kesejahteraan sosial dan pemeliharaan martabat manusia juga dijalankan dengan bentuk dukungan terhadap biaya pendidikan masyarakat. Mekanisme pembagian manfaat dari CBT dilakukan secara adil dan transparan dengan melalui rapat desa bulanan dan Rapat Umum Pemegang Saham di akhir tahun buku.

CBT Desa Sekapuk senantiasa terus menjalin dan meningkatkan hubungan dengan ekonomi lokal dan regional melalui pemberian akses perekonomian terhadap masyarakat setempat sekaligus upaya promosi DTW melalui berbagai media, yang secara logis seiring dengan pertumbuhan kunjungan wisatawan akan mengangkat perekonomian masyarakat, baik yang terlibat langsung di dalam DTW, maupun tidak. Namun demikian, terdapat beberapa catatan yang perlu diperhatikan untuk mengembangkan kinerja CBT di Desa Sekapuk, yaitu dalam aspek: penghargaan terhadap budaya dan tradisi lokal, kontribusi terhadap konservasi sumber daya alam; upaya peningkatan pengalaman pengunjung; dan pengupayaan kemandirian finansial yang kedepannya diharapkan dapat dinikmati oleh lebih banyak masyarakat Desa Sekapuk. 


\section{JPPM (Jurnal Pendidikan dan Pemberdayaan Masyarakat), 8 (1), 2021 - 43}

Agung Yoga Asmoro, Firdaus Yusrizal, Indra Saputra

\section{DAFTAR PUSTAKA}

Aili, L., Jiaming, L., \& Min, L. (2007). Progress in enclave tourism study of overseas: A literature review. Chinese Journal of Population Resources and Environment, 5(3), 76. https://doi.org/10.108o/10042857.2007.10677521

Albert J., S., Dinah, M., \& Unathi Sonwabile, H. (2018). Making Community-Based Tourism Sustainable: Evidence From The Free State Province, South Africa. GeoJournal of Tourism and Geosites, 24(1), 7-18. https://doi.org/10.30892/gtg.24101-338

Amnar, S. (2017). Pengaruh Pariwisata Terhadap Pertumbuhan Ekonomi Di Kota Sabang. Jurnal Ekonomi dan Kebijakan Publik Indonesia, 4(1), 13-22.

Anom, I. P., Suryasih, I. A., Nugroho, S., \& Mahagangga, I. G. A. O. (2017). Turismemorfosis: Tahapan selama seratus tahun perkembangan dan prediksi pariwisata Bali. Jurnal Kajian Bali (Journal of Bali Studies), 7(2), 59. https://doi.org/10.24843/jkb.2017.v07.io2.po4

Asli D.A. Tasci, K. J. S., \& Yilmaz, S. S. (2013). Community Based Tourism Finding the Equilibrium in the COMCEC Context Setting the Pathway for the Future. Comcec Cooordination Office. http://www.mod.gov.tr/Lists/RecentPublications/Attachments/4/COMMUNITY BASED TOURISM Finding the Equilibrium in the COMCEC Context.pdf

Asmoro, A. Y., \& Aziz, M. (2020). Potensi Pengembangan Setigi sebagai Destinasi Wisata. JMK (Jurnal Manajemen dan Kewirausahaan), 5(3), 228-253. https://doi.org/10.32503/jmk.v5i3.1136

Baniya, R., Shrestha, U., \& Karn, M. (2018). Local and Community Well-Being through Community Based Tourism - A Study of Transformative Eff ect. Journal of Tourism and Hospitality Education, 8, 77-96. https://doi.org/10.3126/jthe.v8io.20012

Björk, M., Short, F., Mcleod, E., \& Beer, S. (2008). Managing seagrasses for resilience to climate change (Nomor 3). Iucn.

Cerreta, M., \& Giovene di Girasole, E. (2020). Towards Heritage Community Assessment: Indicators Proposal for the Self-Evaluation in Faro Convention Network Process. Sustainability, 12(23), 9862. https://doi.org/10.3390/su12239862

ChaoZhi, Z., \& MinMin, Z. (2020). The integration of culture and tourism: Multi-understandings, various challenges and approaches. Tourism Tribune, 35(3), 62-71.

CNN Indonesia. (2020). 479 Desa Wisata Jatim Dibuka, Protokol Kesehatan Diperketat. https://www.cnnindonesia.com/nasional/20200706064403-20-521181/479-desa-wisatajatim-dibuka-protokol-kesehatan-diperketat

Cohen, M. (2010). Performing Otherness: Java and Bali on International Stages, 1905-1952. Palgrave Macmillan UK. https://books.google.co.id/books?id=rb-GDAAAQBAJ

Costa, A. P. (2020). Computer Supported Qualitative Research (A. P. Costa, L. P. Reis, \& A. Moreira, Ed.; Vol. 1068). Springer International Publishing. https://doi.org/10.1007/9783-030-31787-4

Davis, J. S., \& Morais, D. B. (2004). Factions and enclaves: Small towns and socially unsustainable tourism development. Journal of Travel Research, 43(1), 3-10. https://doi.org/10.1177/0047287504265501

Desa Sekapuk. (2018). Rancangan Peraturan Desa Sekapuk Nomor o6 Tahun 2018 Tentang Rencana Pembangunan Kepariwisataan Desa Sekapuk.

Desa Sekapuk. (2020). SEKAPUK.DESA.ID - BERSAMA (Berani Sigap Amanah). https://desasekapuk.com/

Dewi, N. I. K., Astawa, I. P., Siwantara, I. W., \& Mataram, I. G. A. B. (2018). Exploring the potential of cultural villages as a model of community based tourism. Journal of Physics: Conference Series, 953, 012072. https://doi.org/10.1088/1742-6596/953/1/012072

Đurkin, J., Perić, M., \& Šebrek, J. (2017). Addressing organisational challenges of cultural tourism in rural areas through community-based tourism model. 145-157. 
JPPM (Jurnal Pendidikan dan Pemberdayaan Masyarakat), 8 (1), 2021 - 44

Agung Yoga Asmoro, Firdaus Yusrizal, Indra Saputra

Fidihama, T. (2019). Sistem Informasi Prioritas Pengembangan Infrastruktur Menggunakan Metode Hanlon Berdasarkan Investasi Warga Desa Sekapuk. http://digilib.uinsby.ac.id/id/eprint/34037

Fitrianto, A. R. (2019). Community Based Tourism In Sekapuk, Ujungpangkah, Sovereignty And Independency Effort In Empowering Local Economy. Prosiding Temu Ilmiah Nasional Balitbang Tahun 2019 "PERCEPATAN PENGEMBANGAN DESA MANDIRI," 325-335.

Freeman, R. E. (2015). Stakeholder Theory. Dalam Wiley Encyclopedia of Management (hlm. 16). American Cancer Society. https://doi.org/10.1002/9781118785317.weomo20179

Freitag, T. G. (1994). Enclave tourism development for whom the benefits roll? Annals of Tourism Research, 21(3), 538-554. https://doi.org/10.1016/0160-7383(94)90119-8

Giampiccoli, A., \& Saayman, M. (2014). A conceptualisation of alternative forms of tourism in relation to community development. Mediterranean Journal of Social Sciences, 5(27), 1667-1677. https://doi.org/10.5901/mjss.2014.v5n27p1667

Gillis, A., \& Jackson, Winston. (2002). Research for nurses: Methods and interpretation. F.A. Davis Co.http://search.ebscohost.com/login.aspx?direct=true\&scope=site\&db=nlebk\&db=nla bk\&AN $=82216$

Gofur, M. A., \& Wesnawa, I. G. A. (2018). Dampak ekologi penambangan batu kapur sebagai bahan dasar pembuatan seen di gunung sadeng kecamatan puger kabupaten jember. Jurnal Pendidikan Geografi Undiksha, 6(3), 163-174.

Hall, C. Michael. (2005). Tourism: Rethinking the social science of mobility. Prentice Hall.

Havadi Nagy, K. X., \& Espinosa Segui, A. (2020). Experiences of community-based tourism in Romania: Chances and challenges. Journal of Tourism Analysis: Revista de Análisis Turístico, ahead-of-p(ahead-of-print). https://doi.org/10.1108/JTA-o8-2019-0033

InfoPublik.id. (2020). Gubernur Jatim Khofifah Kagumi Keindahan Wisata Setigi. http://infopublik.id/kategori/nusantara/471064/gubernur-jatim-khofifah-kagumikeindahan-wisata-setigi

Islam, S. M. N., \& Al-Amin, M. (2019). Measuring the Stakeholders Perceptions of Tourism Promotion in Bangladesh Measuring the Stakeholders Perceptions of Tourism Promotion in Bangladesh. Journal of Business Studies, 40(1), 219-238.

Jammu, A., Khalique, M., Muhammad Khalique, P., Hina, K., Ramayah, T., \& Abdul Nassir bin Shaari, J. (2020). Intellectual capital in tourism SMEs in Understanding Attitude towards Green IT among Professionals in IT Service SMEs in Bangladesh View project Multimedia University View project Intellectual capital in tourism SMEs in SMEs operating in tourism sector 333. Article in Journal of Intellectual Capital, 21(3), 333-355. https://doi.org/10.1108/JIC-11-2018-0206

Jannah, U. (2019). Strategi Bauran Komunikasi Pemasaran Obyek Wisata Baru (Studi Deskriptif Wisata Bukit Kapur Setigi di Desa Sekapuk Kecamatan Ujungpangkah Kabupaten Gresik) [PhD Thesis]. UNIVERSITAS ISLAM NEGERI SUNAN AMPEL SURABAYA.

John, B., \& Elizabeth, W. (2017). Trends that are changing travel and tourism. Worldwide Hospitality and Tourism Themes, 9(6), 592-602. https://doi.org/10.1108/WHATT-o92017-0045

Kaihatu, T. S., Spence, M. T., Kasim, A., Satrya, I. D. G., \& Budidharmanto, L. P. (2020). Millennials' predisposition toward ecotourism: The influence of universalism value, horizontal collectivism and user generated content. Journal of Ecotourism, o(o), 1-20. https://doi.org/10.1080/14724049.2020.1795183

Keputusan Gubernur Jatim No 568 Th 2019 tentang UMK Jatim Th 2020. (2019). Keputusan Gubernur Jatim No 568 Th 2019 tentang UMK Jatim Th 2020.

Khairiah, J. (2009). Pengaruh Perkembangan Pariwisata Terhadap Kebudayaan Dan Bahasa. PhD Thesis: Universitas Sumatera Utara.

Kindon, S. L., Pain, R., \& Kesby, M. (Ed.). (2007). Participatory action research approaches and methods: Connecting people, participation and place. Routledge. 


\section{JPPM (Jurnal Pendidikan dan Pemberdayaan Masyarakat), 8 (1), 2021 - 45}

Agung Yoga Asmoro, Firdaus Yusrizal, Indra Saputra

Kompas.com. (2019). Desa Wisata di Jatim Menggeliat - sukuh.community \ldots. https://sukuh.com/desa-wisata-di-jatim-menggeliat/

Kompas.com. (2020). Uniknya Wisata Setigi di Gresik, Bukit Kapur yang Instagramable Halaman all-Kompas.com. https://travel.kompas.com/read/2020/o8/04/200700527/uniknyawisata-setigi-di-gresik-bukit-kapur-yang-instagramable?page=all

Laire, E., \& Gutierrez, M. (2019). Participation in tourism: Cases on Community-Based Tourism (CBT) in the Philippines. Dalam Ritsumeikan Journal of Asia Pacific Studies (Vol. 37). http://en.apu.ac.jp/rcaps/uploads/fckeditor/publications/journal/2_RJAPS37_Gutierrez .pdf

Leininger, M. M. (1985). Qualitative Research Methods in Nursing. Grune \& Stratton. https://books.google.co.id/books?id=yhttAAAAMAAJ

MacRae, G. (2015). Ubud: "Benteng Terbuka." Recent developments in Bali tourism: Culture, heritage and landscape in an open fortress, March, 69-79.

Maldonado-Erazo, C. P., del Río-Rama, M. de la C., Noboa-Viñan, P., \& Álvarez-García, J. (2020). Community-Based Tourism in Ecuador: Community Ventures of the Provincial and Cantonal Networks. Sustainability, 12(15), 6256. https://doi.org/10.3390/su12156256

Masud, M. M., Aldakhil, A. M., Nassani, A. A., \& Azam, M. N. (2017). Community-based ecotourism management for sustainable development of marine protected areas in Malaysia. Ocean \& Coastal Management, 136, 104-112.

Mayasari, M. (2019). Analisis Pengelolaan Keuangan Badan Usaha Milik Desa (Bumdesa) Di Desa Sekapuk Kecamatan Ujung Pangkah Kabupaten Gresik. http://eprints.umm.ac.id/53252/

Mbaiwa, J. E. (2005). Enclave tourism and its socio-economic impacts in the Okavango Delta, Botswana. Tourism Management, 26(2), 157-172. https://doi.org/10.1016/j.tourman.2003.11.005

Peraturan Menteri Kebudayaan Dan Pariwisata Nomor: PM.26/UM.oo1/MKP/2010 Tentang Pedoman Umum Program Nasional Pemberdayaan Masyarakat (PNPM) Mandiri Pariwisata Melalui Desa Wisata, Pub. L. No. PM.26/UM.oo1/MKP/2010 (2010).

Merriam, S. B., \& Grenier, R. S. (2019). Qualitative Research in Practice: Examples for Discussion and Analysis. Wiley.

Morrissey, J. (2000). Indicators of citizen participation: Lessons from learning teams in rural EZ/EC communities. Community Development Journal, 35(1), 59-74. https://doi.org/10.1093/cdj/35.1.59

Mtapuri, O., \& Giampiccoli, A. (2019). Tourism, community-based tourism and ecotourism: A definitional problematic. South African Geographical Journal, 101(1), 22-35. https://doi.org/10.1080/03736245.2018.1522598

Murphy, P. E. (1985). Tourism: A Community Approach. Routledge. https://books.google.co.id/books?id=EsJ7QgAACAAJ

Nasibah, A. (2019). Analisis Maslahah Mursalah pada Tabungan Plus investasi masyarakat di Desa Sekapuk Ujungpangkah Gresik [PhD Thesis, UNIVERSITAS ISLAM NEGERI SUNAN AMPEL SURABAYA]. http://digilib.uinsby.ac.id/id/eprint/3899o

Neuman, W. L. (2014). Social Research Methods; Qualitative and Quantitative Approaches Seventh Edition. Dalam Pearson. http://arxiv.org/abs/1210.1833\%oAhttp://www.jstor.org/stable/3211488?origin=crossref\% oAhttp://www.ncbi.nlm.nih.gov/pubmed/12655928

Picard, M. (2006). Bali: Pariwisata budaya dan budaya pariwisata. Kepustakaan Populer Gramedia, Forum Jakarta-Paris. https://books.google.co.id/books?id=uwPuIPTuqNMC

Pratiwi, B. D., \& Pinasti, V. I. S. (2017). Pariwisata dan Budaya (Studi Peran Serta Masyarakat Lokal dalam Pengelolaan Pariwisata di Kampung Pitu, Nglanggeran, Patuk, Gunung Kidul). Jurnal Pendidikan Sosiologi, 1(1), 1-11.

Putra, A. P., Wijayanti, T., \& Prasetyo, J. S. (2017). Analisis Dampak Berganda (Multiplier Effect) Objek Wisata Pantai Watu Dodol Banyuwangi. Journal of Tourism and Creativity, 2(1), 141. 
JPPM (Jurnal Pendidikan dan Pemberdayaan Masyarakat), 8 (1), 2021 - 46

Agung Yoga Asmoro, Firdaus Yusrizal, Indra Saputra

Ravindra Deyshappriya, N. P. (2020). ADBI Working Paper Series TOURISM AND SME DEVELOPMENT: PERFORMANCE OF TOURISM SMES IN COASTAL TOURIST DESTINATIONS IN SOUTHERN SRI LANKA Asian Development Bank Institute (No. 1164). https://www.adb.org/publications/tourism-sme-development-southern-sri-lanka

Sacco, B., \& Cassar, I. (2019). Measuring the economic impact of tourism in Malta using the Tourism Satellite Account. European Journal of Tourism Research, 23, 86-111.

Shaw, B. J., \& Shaw, G. (1999). "Sun, Sand and Sales": Enclave Tourism and Local Entrepreneurship in Indonesia. Current Issues in Tourism, 2(1), 68-81. https://doi.org/10.108o/13683509908667844

Sheldon, P. J., \& Fesenmaier, D. R. (2017). Social Entrepreneurship and Tourism (P. J. Sheldon \& R. Daniele, Ed.). Springer International Publishing. https://doi.org/10.1007/978-3-31946518-o

Srithong, S., Suthitakon, N., \& Karnjanakit, S. (2019). Participatory Community-based Agrotourism: A Case Study of Bangplakod Community, Nakhonnayok Province, Thailand. PSAKU International Journal of Interdisciplinary Research, 8(1).

Streubert, H. J., Speziale, H. S., \& Carpenter, D. R. (1995). Qualitative Research in Nursing: Advancing the Humanistic Imperative. Lippincott. https://books.google.co.id/books?id=_RitAAAAMAAJ

Sutono, A. (2020). PARIWISATA DAN KETAHANAN NASIONAL (Percepatan Pembangunan Pendidikan Vokasi Bidang Pariwisata Berbasis Penta Helix Guna Peningkatan Daya Saing Bangsa dalam Rangka Ketahanan Nasional). LEMHANAS RI.

Sutresna, I. B., Suyana, U. I. M., Saskara, I. A. N., \& Wiwin, S. N. P. (2019). COMMUNITY BASED TOURISM AS SUSTAINABLE TOURISM SUPPORT. Russian Journal of Agricultural and Socio-Economic Sciences, 94(10), 70-78. https://doi.org/10.18551/rjoas.2019-10.09

Suwanna, A., \& Chaikasem, T. (2018). COMMUNITY BASED TOURISM AND SUBJECTIVE WELL-BEING. INCBAA 2018, Khon Kaen, THAILAND.

Swesti, W. (2019). MASYARAKAT DI BANDA ACEH The Social-Cultural Impact of Tourism In Banda Aceh. Jurnal Kepariwisataan Indonesia, 13(2), 49-65.

Syukur, A. (2016). Konservasi Lamun untuk Keberlanjutan Sumberdaya Ikan di Perairan Pesisir Indonesia. Jurnal Biologi Tropis, 16(1). https://doi.org/10.29303/jbt.v16i1.217

The ASEAN Secretariat. (2016). Asean Community Based Tourism Standard. The ASEAN Secretariat.

TribunNews.com. (2020a). Jelang New Normal, Wisata Setigi Gresik Diizinkan Buka Lagi, dan Wakili Gresik di Lomba Nasional-Tribun Jatim. https://jatim.tribunnews.com/2020/o6/o3/jelang-new-normal-wisata-setigi-gresikdiizinkan-buka-lagi-dan-wakili-gresik-di-lomba-nasional

TribunNews.com. (2020b). Khofifah Dorong Wisata Setigi Sekapuk Gresik Dapat Program Pemulihan Ekonomi Nasional-Surya. https://surabaya.tribunnews.com/2020/o7/29/khofifah-dorong-wisata-setigi-sekapukgresik-dapat-program-pemulihan-ekonomi-nasional

TribunNews.com. (2020c). Wisata Tangguh Setigi Sekapuk di Gresik Utara Jadi Destinasi Wisata Era New Normal-Surya. https://surabaya.tribunnews.com/2020/o6/o1/wisata-tangguhsetigi-sekapuk-di-gresik-utara-jadi-destinasi-wisata-era-new-normal

Twining-Ward, L. (2007). A Toolkit for Monitoring and Managing Community-Based Tourism. SNV - University of Hawaii, $1-85$.

UIN Sunan Ampel Surabaya. (2015). Community based Research-Panduan Merancang dan Melaksanakan Penelitian Bersama Komunitas. LEMBAGA PENELITIAN DAN PENGABDIAN KEPADA MASYARAKAT UIN SUNAN AMPEL SURABAYA.

Undang-Undang Republik Indonesia Nomor 10 TAHUN 2009 tentang Kepariwisataan. (2009). Undang-Undang Republik Indonesia Nomor 10 TAHUN 2009 tentang Kepariwisataan.

Valsa, K. (2005). Action research for improving practice-A Practical Guide. Dalam A SAGE Publication Campany (Vol. 36). Paul Chapman Publishing. 
JPPM (Jurnal Pendidikan dan Pemberdayaan Masyarakat), 8 (1), 2021 - 47

Agung Yoga Asmoro, Firdaus Yusrizal, Indra Saputra

Vickers, A. (2019). Creating heritage in Ubud, Bali. Wacana, 20(2), 250-265. https://doi.org/10.17510/wacana.v2oi2.747

Wang, Y.-L. (2020). Research on the Cultivation of Professional International Talents Based on Local Characteristic Tourism Development. DEStech Transactions on Social Science, Education and Human Science, icesd, 777-781. https://doi.org/10.12783/dtssehs/icesd2020/34170

Wardhana, A. T., Syahid, A., Rizalzi, D., Kartiko, F. R., Lestari, I., Tekmauk, J. V., Grasella, L., Nurul, R., Kastera, V., \& Sari, A. S. (2020). PEMANFAATAN LAHAN BEKAS TAMBANG PT. POLOWIJO GOSARI SEBAGAI GEO WISATA KARST KAB. GRESIK, PROVINSI JAWA TIMUR. Seminar Teknologi Kebumian dan Kelautan (SEMITAN II) Institut Teknologi Adhi Tama Surabaya (ITATS), Indonesia, 12 Juli 2020, 2(1), 239-245.

Yanes, A., Zielinski, S., Cano, M. D., \& Kim, S. I. (2019). Community-based tourism in developing countries: A framework for policy evaluation. Sustainability (Switzerland), 11(9), 1-23. https://doi.org/10.3390/su11092506

Zielinski, S., Jeong, Y., \& Milanés, C. B. (2020). Factors that influence community-based tourism (CBT) in developing and developed countries. Tourism Geographies, o(o), 1-33. https://doi.org/10.108o/14616688.2020.1786156 